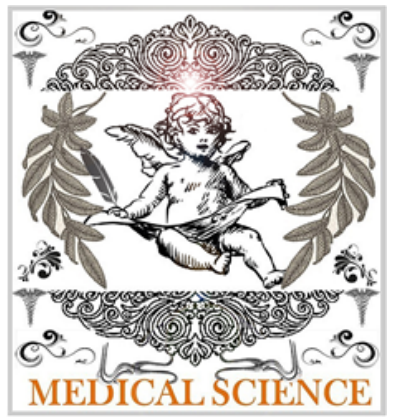

\title{
Impact of Gender, Nationality and Drawbacks in Medical Profession as a Predictor of Future Career Specialization among Medical Students
}

\section{Roy $B^{1}$, Banerjee $I^{2}$, Banerjee $I^{3}$, Sathian $B^{4}$, Baboo $N^{5}$}

\section{Abstract}

Background: Diverse factors play a crucial role on the Career Preferences among medical students. Hospital-based clinical specialties are always preferred. Nepal had very scanty data on this topic. So this study was designed to examine the influence of gender and nationality, some other dominant factors including drawbacks in future career preferences.

Methods: A questionnaire-based study was carried out in the Basic and clinical Sciences Campus of Manipal College of Medical Sciences, Pokhara, Nepal. Students from Nepal, India and Sri Lanka participated in the study. The questionnaire included awareness and liking of different subjects for post-graduation, decision age for MBBS and various other factors. Descriptive statistics and testing of hypothesis were used for the analysis. The Chi-square test was performed. Data was analyzed using Statistical Package for the Social Sciences (SPSS) for Windows Version 16.0.

Results: Data was collected from 269 students and among them were 110 Nepalese (40.9\%), 85 Indian (31.6\%) and 74 Sri Lankan (27.5\%). Indian students had relatively more awareness about their future career. Females were more aware about future career and happy with routine work, diversity in work, physical and team work. Communication skills, long relation with patients, simple complaints and stressful work attract males. Surgery, OBG, Pediatrics, Neurosurgery, Cardiology were the most desirable specialty among both genders.

Conclusion: The findings of this study were imperative and provide ample career guidance for future doctors to fill the gap in different specialties. Constructive steps like encouragement, counseling can be helpful in this context.

Keywords: fascination, medical education, motivation.

\section{Corresponding Author:}

${ }^{1}$ Bedanta Roy M.Sc, PhD, Asst. Prof. MCOMS email: bedanta.roy@gmail.com

${ }^{2}$ Indraneel Banerjee MBBS, M.S, MRCS( Eng ), CNMC

${ }^{3}$ Indrajit Banerjee MBBS, MD Pharmacology, MCOMS

${ }^{4}$ Brijesh Sathian MD(AM), PhD, MCOMS

${ }^{5} \mathrm{~N}$ Suresh Baboo, DNB, M.D, MCOMS

Full list of author information is available at the end of the article

\section{Background}

Diverse factors influence medical students career choice [1]. Proper counseling and guidance is required for choosing medical specialization fields. During medical school, medical students develop interest in one or more specialty careers based on their knowledge [2]. Other dynamic factors that are expected to play a vital role include the characteristics of the medical college, lifestyle preferences, prestige, drawbacks, job opportunities, expected earnings, longitudinal care, preclinical and clinical familiarity, and role models [3-5]. Some other regulating key factors include gender, study debt, and academic credentials [69]. Medical curriculum in Nepal is divided into basic sciences and clinical sciences. Basic Science subjects are taught in first two years and Clinical subjects throughout the last five semesters (two and half years) of this professional course [10, 11]. Tribhuvan University (TU), Kathmandu University (KU), BP Koirala Institute of Health Sciences (BPKIHS) and NAMS (National Academy of Medical Sciences) are conducting postgraduate degree programs in different subjects. TU led the way for starting postgraduate courses in Institute of Medicine [12]. At the Manipal College of Medical Sciences (MCOMS), 
Pokhara, Nepal, a large number of students are coming from Nepal, India, Sri Lanka and other countries. These students have various cultural, socioeconomic and educational backgrounds. Though, so far, most studies have been carried out using the US medical student population and data from other countries are deficient [6,13]. Few research studies conducted in Asia suggested that hospital-based clinical specialties are always preferred and practice in main cites are always opted [14-16]. Hence the present study was undertaken with the following objectives:

1. Find out the influence of gender, nationality in carrier choice of medical students

2. Disadvantageous aspects of medical profession and other influential factors as a determinant for the choice of future specialization.

\section{Material and Methods:}

\section{Setting and participants}

A cross-sectional, questionnaire-based study was carried out at Manipal College of Medical Sciences, which is affiliated to Kathmandu University, Nepal. Each year MCOMS admits students for MBBS course. The students of basic and clinical sciences were invited to take part in the study. They voluntarily and anonymously completed a questionnaire. The authors gave a look at motives of students for refusal to be a participant. A few probable reasons were the waste of time due to length of the questionnaire and the students being out of station during the study period.

\section{Questionnaire design}

Survey was done by using a self-administered questionnaire. The current study was completed between 1st September to 31st November 2012 among basic and clinical sciences undergraduate medical students. A review of the literature was done to prepare questionnaire based on demographic details, important motives, factors related to career choice like awareness and fascination, post-graduation, decision age for MBBS, and drawbacks along with a list of medical specialties. A pilot study of 30 students was conducted and the results were discussed among the authors. It covered both personal and educational aspects. In the beginning of the study, students were briefed about the purpose of the study. Confidentiality and anonymity was maintained throughout the study.

Few questions were asked about general characteristics of the medical profession, phrased as "To what extent does this characteristic apply to the profession", with a 5-point rating scale, ranging from 1 (not very attractive at all) to 5 (very attractive), based on earlier research about student's perception of the medical profession $[17,18]$.

\section{Data collection}

Two authors of this paper collected data personally from the completed questionnaires of 269 students. Students were asked to answer each question honestly and appropriately. Their identity was set aside confidential to avoid study bias. Instruction form and questionnaire was taken from the students after the study.

\section{Sample size calculation}

By conducting a pilot study of 30 students it is estimated that for $99 \%$ confidence interval and, significance level $\alpha=1 \%, P=70 \%$, $\mathrm{Q}=30 \%$, allowable error $=10 \%$, required sample size was 218 . $P$ $=$ percentage of students opted their post graduation in Clinical subjects [19].

\section{Outcome variables}

The choices of subjects (Neurology, Surgery, Neurosurgery, Pediatrics, Obstetrics and Gynecology etc.) were used as a dependent variable.

\section{Explanatory variables}

The demographic and other factors those influenced choices were assessed at individual level. These factors were age, gender, nationality, decision age for MBBS, drawbacks in medical profession etc. were also considered in the preference of one's career.

\section{Ethical Committee approval}

Before proceeding to the study, approval was taken from college ethical Committee.

\section{Data management and statistical analysis}

Descriptive statistics and testing of hypothesis were used for the analysis. The data was analyzed using Statistical Package for the Social Sciences (SPSS) for Windows Version 20.0 (SPSS Inc; Chicago, IL, USA). The Chi-square test was used to examine the association between different variables. $\mathrm{P}<0.05$ was considered as statistically significant.

\section{Results:}

Basic demographics

Questioner was distributed among 338 medical students (i.e. 290 basic science and 235 clinical science students). Among 
Table - 1: Diverse factors influencing Nepalese, Indian and Srilankan students for specialist training

\begin{tabular}{|c|c|c|c|}
\hline \multicolumn{4}{|c|}{ Nepalese students } \\
\hline & \multicolumn{2}{|c|}{ Number $\{$ Mean \pm SD [CI]\} of Nepalese students } & \multirow[t]{2}{*}{ P value } \\
\hline & Male & Female & \\
\hline Communication skills & $3.94 \pm 1.37[3.59-4.28]$ & $3.64 \pm 1.57[3.18-4.10]$ & $0.300 x$ \\
\hline Long relation with patients & $3.81 \pm 1.20[3.51-4.11]$ & $3.81 \pm 1.17[3.46-4.15]$ & $0.996 x$ \\
\hline Simple complaints & $2.73 \pm 0.99[2.48-2.98]$ & $2.72 \pm 1.10[2.40-3.05]$ & $0.973 \times$ \\
\hline Routine work & $3.43 \pm 1.088[3.15-3.70]$ & $3.17 \pm 1.13[2.84-3.50]$ & $0.231 \times$ \\
\hline Diversity of work & $3.86 \pm 0.90[3.63-4.08]$ & $3.60 \pm 0.97[3.31-3.89]$ & $0.152 \times$ \\
\hline Physical work & $3.80 \pm 1.17[3.50-4.09]$ & $3.75 \pm 1.22[3.39-4.10]$ & $0.833 \times$ \\
\hline Team work & $3.94 \pm 1.06[3.67-4.20]$ & $3.79 \pm 1.28[3.41-4.16]$ & $0.518 \times$ \\
\hline Stressful work & $2.71 \pm 1.14[2.43-3.00]$ & $2.53 \pm 1.32[2.15-2.92]$ & $0.449 x$ \\
\hline \multicolumn{4}{|c|}{ Indian students } \\
\hline & \multicolumn{2}{|c|}{ Number $\{$ Mean $\pm S D[C I]\}$ of Indian Students } & \multirow[t]{2}{*}{ P value } \\
\hline & Male & Female & \\
\hline Communication skills & $4.10 \pm 1.39[3.71-4.49]$ & $4.17 \pm 1.32[3.72-4.62]$ & $0.811 \times$ \\
\hline Long relation with patients & $3.70 \pm 1.15[3.37-4.03]$ & $3.77 \pm 1.21[3.35-4.19]$ & $0.786 \times$ \\
\hline Simple complaints & $3.08 \pm 1.01[2.79-3.37]$ & $2.60 \pm 0.91[2.29-2.91]$ & $0.025^{*}$ \\
\hline Routine work & $3.04 \pm 1.18[2.71-3.37]$ & $3.57 \pm 1.07[3.21-3.94]$ & $0.033^{*}$ \\
\hline Diversity of work & $3.38 \pm 0.83[3.14-3.62]$ & $4.17 \pm 0.92[3.85-4.49]$ & $0.0001+$ \\
\hline Physical work & $3.30 \pm 1.30[2.93-3.67]$ & $3.71 \pm 1.34[3.25-4.17]$ & $0.160 \times$ \\
\hline Team work & $3.52 \pm 1.09[3.21-3.83]$ & $3.91 \pm 1.27[3.48-4.35]$ & $0.141 \times$ \\
\hline Stressful work & $2.86 \pm 1.18[2.53-3.19]$ & $2.57 \pm 1.20[2.16-2.98]$ & $0.274 \times$ \\
\hline \multicolumn{4}{|c|}{ SriLankan students } \\
\hline & \multicolumn{2}{|c|}{ Number $\{$ Mean \pm SD [Cl]\}of Sri Lankan students } & \multirow[t]{2}{*}{ P value } \\
\hline & Male & Female & \\
\hline Communication skills & $4.09 \pm 1.55[3.53-4.65]$ & $3.64 \pm 1.69$ [3.12-4.17] & $0.238 x$ \\
\hline Long relation with patients & $4.00 \pm 1.02[3.63-4.37]$ & $3.76 \pm 1.12$ [3.41-4.11] & $0.343 x$ \\
\hline Simple complaints & $3.13 \pm 0.91[2.80-3.45]$ & $3.00 \pm 1.06$ [2.67-3.33] & $0.587 x$ \\
\hline Routine work & $2.84 \pm 0.99[2.49-3.20]$ & $3.00 \pm 1.10$ [2.66-3.34] & $0.524 \times$ \\
\hline Diversity of work & $3.81 \pm 0.97[3.46-4.16]$ & $3.83 \pm 0.93[3.54-4.12]$ & $0.926 x$ \\
\hline Physical work & $3.16 \pm 1.37[2.66-3.65]$ & $3.40 \pm 1.34[2.99-3.82]$ & $0.439 x$ \\
\hline Team work & $3.91 \pm 0.93[3.57-4.24]$ & $3.90 \pm 1.01[3.60-4.22]$ & $0.995 \times$ \\
\hline Stressful work & $2.91 \pm 1.40[2.40-3.41]$ & $2.69 \pm 1.39[2.26-3.12]$ & $0.512 x$ \\
\hline
\end{tabular}

$x p>0.05$, statistically not significant

$* p<0.05$, statistically significant

$+p<0.01$, statistically significant

them 269 answered the questionnaire completely and correctly, giving an overall response rate of $79.58 \%$ (basic science $82.4 \%$ and clinical science $71.5 \%$ ). Incorrect and incomplete questionnaires were excluded from the analysis. The mean age of Indian (85, 31.6\%), Nepalese $(110,40.9 \%)$ and Sri Lankan (74, $27.5 \%)$ students were $18.3 \pm$ SD 0.7, $18.6 \pm$ SD 0.8 and $18.0 \pm$ SD 1.5 years respectively. Majority of the students were Hindu (61.4\% Indians and $89.6 \%$ Nepalese) while in Sri Lankan students, the majority (53.8\%) were Buddhist.

Table-1 shows Nepalese Males preferred communication skills, routine work, diversity of work, physical work, team work, stressful work. Indian Females preferred communication skills (NS), long relation with patients (NS), routine work $(p<0.05)$, diversity of work ( $p<0.001)$, physical (NS) and team work (NS) as

Medical Science 2013;1(1): 3-11

Copyright (C) 2013 CMRA

www.medicalscience.pubmedhouse.com compared to males. Simple complaints $(p<0.05)$ and stressful works (NS) were preferred more by males. Srilankan females also preferred routine work, diversity of work, physical work. Communication skills, long relation with patients liked by males. The differences between the genders are not significant in any of the parameters.

Table-2 explains that $15-18$ years is the commonest age taking decision to come into medical field. This is more prominent in females $(52.4 \%)$ compared to males (37.9\%). Taking decision at the age of $7-12 y r s(20 \%), 12-15 y r s(22.1 \%)$ and $18-20 y r s(13.8 \%)$ were relatively more in males then females. 
Table - 2: Decision age to join in MBBS course

\begin{tabular}{|c|c|c|c|c|c|c|c|}
\hline & \multicolumn{6}{|c|}{ Number $\{\mathrm{n}(\%)\}$ of students and their Decision age for MBBS } & $\begin{array}{c}P \\
\text { value }\end{array}$ \\
\hline $\begin{array}{c}\text { Gend } \\
\text { er }\end{array}$ & $\begin{array}{c}\text { less } \\
\text { than } \\
7 \\
\text { years }\end{array}$ & $\begin{array}{c}7-12 \\
\text { years }\end{array}$ & $\begin{array}{l}12-15 \\
\text { years }\end{array}$ & $\begin{array}{l}15-18 \\
\text { years }\end{array}$ & $\begin{array}{l}18-20 \\
\text { years }\end{array}$ & Total & \multirow[t]{3}{*}{$\begin{array}{c}0.045 \\
*\end{array}$} \\
\hline Male & $\begin{array}{c}9 \\
(6.2)\end{array}$ & $\begin{array}{c}29 \\
(20)\end{array}$ & $\begin{array}{c}32 \\
(22.1)\end{array}$ & $\begin{array}{c}55 \\
(37.9)\end{array}$ & $\begin{array}{c}20 \\
(13.8)\end{array}$ & $\begin{array}{c}145 \\
(100)\end{array}$ & \\
\hline $\begin{array}{c}\text { Femal } \\
\text { e }\end{array}$ & $\begin{array}{c}11 \\
(8.9)\end{array}$ & $\begin{array}{c}21 \\
(16.9)\end{array}$ & $\begin{array}{c}20 \\
(16.1)\end{array}$ & $\begin{array}{c}65 \\
(52.4)\end{array}$ & $\begin{array}{c}7 \\
(5.6)\end{array}$ & $\begin{array}{c}124 \\
(100)\end{array}$ & \\
\hline
\end{tabular}

* $\mathrm{p}<0.05$, statistically significant

Table-3 clarify most of the students had chosen surgery as specialty pointed out poor quality of life, exclusively hospital based career, judicial proceedings, workload, competition as drawbacks. In Neurosurgery specialization willing students judicial proceedings got priority, followed by poor quality of life, exclusively hospital based career etc. Students, attracted towards pediatrics, spotted out workload, poor quality of life and judicial proceedings as main disadvantageous aspect. Obstetrics and Gynecology as future career pointed out poor quality of life, exclusively hospital based career as a main snag. Students selected Medicine, focused on judicial proceedings, exclusively hospital based career and competition as drawback.

Table-4 illustrates that most of the students who had chosen Surgery as specialty exhibit interest in human body as a major influential factor, followed by practical aspect of profession, social contact with people, etc. Students who preferred Neurosurgery got fascinated by the verity of scope mostly and others gave equal priority to interest in human body, helping people and interest in research fulfillment as the encouraging factors. Students opted pediatrics spotted out helping people as the most important factor, followed by practical aspect of profession, interest in research fulfillment etc. Obstetrics and Gynecology preferred by students mainly focused on helping people, interest in human body, followed by social contact with people, practical aspect of profession etc. Students opted Medicine, gave importance on verity of scope, followed by interest in human body and helping people.

\section{Discussion}

\section{Country wise fascination of diverse factors}

Among Nepalese male students, communication skills, routine work, diversity of work, physical work, team work and stressful work also got significance because they are hard working. Medical education system in Nepal is yet to be flourished properly so most of the students want to stay in home country for the welfare of their co-citizens and ready to combat with emergent situations. In a study of 469 medical students by Huntington et al states that $88 \%$ was likely to practice in Nepal [20]. Among Indian females communication skills, long relation with patients, routine work etc. were more attractive contrasted with males. Research study done in Jordon by Yousef Khader had shown that $34.3 \%$ of males and $38.8 \%$ females were interested in long term relations with patients [21]. Other researchers Scott et al, reported that among different variables, long-term patient relationship was important most for family medicine, followed by medical specialty, surgical specialty, emergency medicine [22]. Preference for stressful work by males may be that they will be able to cope better with stress than by females. Our study is quite similar with other researchers like Sheikh et al, where girls had stated that examinations, family and relationship problems more commonly as the cause for their strain when compared with male colleagues [23]. Among Sri Lankan females, routine work, diversity of work, physical work was more attractive contrasted with males. A study by Tennakoon showed that among Sri Lankan medical students, working conditions and working hours had some influence, $51.31 \%$ and $43.98 \%$ respectively, in their career choice [24]. Communication skills, long relation with patients, simple complaints and stressful work are liked by males.

\section{Gender and decision age for MBBS}

Male students took early decision for admission to join MBBS course. Other studies revealed motivational factors for delayed entry of elder candidates consist of late consideration of medicine as a career (34.7\%), financial problems (31.4\%), and dissatisfaction with previous career (30.6\%), poor academic results (19.8\%), or a combination of the above factors [25].

\section{Drawbacks of the opted specialty and choice of subjects:}

Medical profession has several disadvantages which lead to burnout and anxiety of medical students [26,27]. Most of the students had chosen surgery as specialty pointed out poor quality of life, exclusively hospital based career, judicial proceedings, workload, competition as drawbacks. Earlier studies proved that there is inability to achieve work - life balance; it was more in females (35.3\%) than in males $(32.7 \%)$ [28]. Research works in Neurosurgical field suggested that some major stressors included in this area were patient care, communication, workload, management and supervision, organizational and personal circumstances [29]. The present study also supports this. In a similar study Atalaya found that $33.8 \%$ of the study population had alarmingly high level of emotional exhaustion in Obstetrics \& Gynecology specialty and 
Table - 3: Cross tabulation of drawbacks of the opted specialty and choice of subjects

\begin{tabular}{|c|c|c|c|c|c|c|c|c|c|c|c|c|c|c|}
\hline \multirow[b]{2}{*}{ Choice of Subjects } & \multicolumn{12}{|c|}{ Drawbacks } & \multirow[b]{2}{*}{ Total } & \multirow[b]{2}{*}{$\begin{array}{l}P \\
\text { value }\end{array}$} \\
\hline & $\begin{array}{l}\text { Poor } \\
\text { quali } \\
\text { ty of } \\
\text { life }\end{array}$ & $\begin{array}{l}\text { Exclusiv } \\
\mathrm{e} \\
\text { hospita } \\
\text { I based } \\
\text { career }\end{array}$ & $\begin{array}{l}\text { Loss } \\
\text { of } \\
\text { pati } \\
\text { ent } \\
\text { cont } \\
\text { act }\end{array}$ & $\begin{array}{l}\text { No } \\
\text { techn } \\
\text { ical } \\
\text { activi } \\
\text { ty }\end{array}$ & $\begin{array}{l}\text { Workl } \\
\text { oad }\end{array}$ & $\begin{array}{l}\text { No } \\
\text { private } \\
\text { practic } \\
\text { e }\end{array}$ & $\begin{array}{l}\text { Drug } \\
\text { addicte } \\
\text { d } \\
\text { patient } \\
\text { s }\end{array}$ & $\begin{array}{l}\text { Chron } \\
\text { ic } \\
\text { diseas } \\
\text { es }\end{array}$ & $\begin{array}{l}\text { Judicial } \\
\text { procee } \\
\text { dings }\end{array}$ & $\begin{array}{l}\text { Compe } \\
\text { tition }\end{array}$ & $\begin{array}{l}\text { Cancer } \\
\text { or fatal } \\
\text { disease } \\
\mathrm{s}\end{array}$ & $\begin{array}{l}\text { Excess } \\
\text { clinical } \\
\text { activities }\end{array}$ & & \\
\hline Neurology & 1 & 0 & 0 & 0 & 0 & 0 & 0 & 0 & 0 & 0 & 0 & 0 & 1 & \multirow{28}{*}{$0.9 x$} \\
\hline Surgery & 18 & 10 & 5 & 4 & 8 & 2 & 1 & 2 & 10 & 7 & 3 & 2 & 72 & \\
\hline Neurosurgery & 3 & 3 & 1 & 0 & 0 & 2 & 0 & 0 & 4 & 3 & 0 & 0 & 16 & \\
\hline Pediatrics & 6 & 3 & 0 & 1 & 8 & 0 & 1 & 0 & 2 & 1 & 0 & 0 & 22 & \\
\hline OBG & 7 & 7 & 2 & 0 & 1 & 0 & 0 & 0 & 6 & 9 & 1 & 1 & 34 & \\
\hline Medical research & 2 & 1 & 0 & 0 & 2 & 1 & 0 & 0 & 0 & 2 & 0 & 0 & 8 & \\
\hline Medicine & 1 & 6 & 0 & 0 & 2 & 0 & 0 & 1 & 7 & 4 & 0 & 0 & 21 & \\
\hline CVS surgery & 6 & 2 & 0 & 0 & 2 & 0 & 0 & 0 & 1 & 2 & 0 & 0 & 13 & \\
\hline Public health & 1 & 2 & 1 & 0 & 0 & 0 & 0 & 0 & 0 & 0 & 0 & 0 & 4 & \\
\hline Geriatrics & 0 & 1 & 0 & 0 & 2 & 0 & 0 & 1 & 1 & 0 & 0 & 0 & 5 & \\
\hline Anesthetics & 0 & 0 & 1 & 1 & 0 & 0 & 0 & 0 & 0 & 0 & 0 & 0 & 2 & \\
\hline Cardiology & 6 & 5 & 0 & 0 & 1 & 0 & 0 & 0 & 0 & 2 & 1 & 0 & 15 & \\
\hline Traumatic & 1 & 0 & 1 & 1 & 1 & 0 & 0 & 0 & 1 & 3 & 0 & 0 & 8 & \\
\hline Armed forces & 1 & 0 & 0 & 0 & 1 & 0 & 0 & 0 & 1 & 0 & 0 & 0 & 3 & \\
\hline Oncology & 2 & 1 & 0 & 0 & 0 & 0 & 0 & 0 & 1 & 1 & 0 & 0 & 5 & \\
\hline Radiology & 1 & 0 & 0 & 0 & 0 & 0 & 0 & 0 & 0 & 0 & 0 & 1 & 2 & \\
\hline Orthopedics & 1 & 1 & 0 & 0 & 0 & 0 & 0 & 0 & 1 & 0 & 0 & 0 & 3 & \\
\hline General practice & 0 & 1 & 0 & 0 & 2 & 0 & 0 & 0 & 1 & 4 & 0 & 0 & 8 & \\
\hline Ophthalmology & 0 & 1 & 1 & 0 & 0 & 0 & 0 & 0 & 1 & 1 & 0 & 0 & 4 & \\
\hline Pathology & 0 & 2 & 0 & 0 & 1 & 0 & 0 & 0 & 1 & 0 & 0 & 0 & 4 & \\
\hline Gastroenterology & 2 & 0 & 0 & 0 & 0 & 0 & 0 & 0 & 0 & 0 & 0 & 0 & 2 & \\
\hline Nephrology & 0 & 0 & 0 & 0 & 1 & 0 & 0 & 0 & 1 & 0 & 0 & 0 & 2 & \\
\hline Forensic science & 1 & 1 & 0 & 0 & 0 & 0 & 0 & 0 & 1 & 1 & 0 & 0 & 4 & \\
\hline Maxillofacial & 0 & 0 & 0 & 0 & 0 & 0 & 0 & 0 & 1 & 1 & 0 & 0 & 2 & \\
\hline Dermatology & 2 & 0 & 0 & 2 & 0 & 0 & 0 & 0 & 0 & 1 & 0 & 0 & 5 & \\
\hline Psychiatry & 1 & 0 & 0 & 0 & 0 & 0 & 0 & 0 & 0 & 1 & 0 & 0 & 2 & \\
\hline Microbiology & 0 & 0 & 0 & 0 & 0 & 1 & 0 & 0 & 0 & 1 & 0 & 0 & 2 & \\
\hline Total & 63 & 47 & 12 & 9 & 32 & 6 & 2 & 4 & 41 & 44 & 5 & 4 & 269 & \\
\hline
\end{tabular}

$x p>0.05$, statistically not significant

this problem is elevated in medical specialists (52.3\%) [30]. In the field of medicine, perceived working conditions were more important than the actual workload to explain the variance in burnout. In addition, burnout in medical specialists and residents was linked to different characteristics of their working environment [31].

Results of this study also support it. Cardiology residents in Argentina exhibit high levels of burnout, perceived stress, and depressive symptoms, which warrants greater attention to the psychological needs of residents [32]. Outcomes of present study regarding cardiology specialization also pointed out towards poor quality of life and exclusively hospital based career as a major negative aspect [28].

\section{Factors influenced and choice of subjects}

Surgery specialty opting students pointed out interest in human body as a major influential factor, followed by practical aspect, social contact, Interest in research fulfillment and verity of scope. Study done by Troppmann showed that $85 \%$ of the respondents were happy with their careers. Apart from this, some factors like technical aspects, the influential nature, the intellectual challenges of the profession, factors like helping others, were played a key role. This study also supports it [28]. Most of the undergraduate students are attracted towards medicine and surgery, male gender was positively associated with a preference for a career in surgery and female's attitude was towards medicine. They were less interested towards basic medical science and Social and Preventive Medicine [10]. Some research articles states that pediatric surgical specialization is 
Table - 4: Cross tabulation of factors influenced and choice of subjects

\begin{tabular}{|c|c|c|c|c|c|c|c|c|c|c|c|c|c|}
\hline \multirow[b]{2}{*}{$\begin{array}{l}\text { Choice of } \\
\text { subjects }\end{array}$} & \multicolumn{11}{|c|}{ Factors influenced } & \multirow[b]{2}{*}{ Total } & \multirow[b]{2}{*}{$P$ value } \\
\hline & $\begin{array}{c}\text { Intere } \\
\text { st in } \\
\text { huma } \\
n \\
\text { body }\end{array}$ & $\begin{array}{l}\text { Helpin } \\
\mathrm{g} \\
\text { people }\end{array}$ & $\begin{array}{l}\text { Social } \\
\text { conta } \\
\text { ct } \\
\text { with } \\
\text { peopl } \\
\text { e }\end{array}$ & $\begin{array}{l}\text { Practical } \\
\text { aspect } \\
\text { of } \\
\text { professi } \\
\text { on }\end{array}$ & $\begin{array}{l}\text { Varit } \\
\text { y of } \\
\text { scop } \\
\text { e }\end{array}$ & $\begin{array}{c}\text { Problem } \\
\text { oriented } \\
\text { aspect }\end{array}$ & $\begin{array}{l}\text { Interes } \\
t \text { in } \\
\text { researc } \\
h \\
\text { fulfillm } \\
\text { ent }\end{array}$ & $\begin{array}{l}\text { Personal } \\
\text { experienc } \\
\text { e with } \\
\text { illness or } \\
\text { health }\end{array}$ & $\begin{array}{c}\text { Doctor(s) } \\
\text { as } \\
\text { example in } \\
\text { your own } \\
\text { environme } \\
\text { nt }\end{array}$ & $\begin{array}{l}\text { Anticipat } \\
\text { ed salary }\end{array}$ & $\begin{array}{c}\text { Care } \\
\text { er }\end{array}$ & & \\
\hline Neurology & 0 & 0 & 0 & 0 & 0 & 0 & 0 & 0 & 0 & 1 & 0 & 1 & \multirow{23}{*}{$0.0001+$} \\
\hline Surgery & 16 & 9 & 10 & 11 & 7 & 4 & 9 & 0 & 2 & 2 & 2 & 72 & \\
\hline Neurosurgery & 3 & 3 & 1 & 0 & 4 & 0 & 3 & 0 & 2 & 0 & 0 & 16 & \\
\hline Pediatrics & 2 & 9 & 1 & 5 & 0 & 2 & 3 & 0 & 0 & 0 & 0 & 22 & \\
\hline OBG & 10 & 11 & 6 & 4 & 2 & 0 & 0 & 0 & 0 & 0 & 1 & 34 & \\
\hline Medical research & 0 & 3 & 0 & 0 & 1 & 0 & 4 & 0 & 0 & 0 & 0 & 8 & \\
\hline Medicine & 4 & 4 & 1 & 2 & 6 & 0 & 0 & 0 & 1 & 0 & 3 & 21 & \\
\hline CVS surgery & 3 & 7 & 0 & 2 & 1 & 0 & 0 & 0 & 0 & 0 & 0 & 13 & \\
\hline Public health & 0 & 0 & 2 & 0 & 0 & 2 & 0 & 0 & 0 & 0 & 0 & 4 & \\
\hline Geriatrics & 0 & 0 & 3 & 0 & 2 & 0 & 0 & 0 & 0 & 0 & 0 & 5 & \\
\hline Anesthetics & 0 & 0 & 2 & 0 & 0 & 0 & 0 & 0 & 0 & 0 & 0 & 2 & \\
\hline Cardiology & 4 & 0 & 3 & 3 & 5 & 0 & 0 & 0 & 0 & 0 & 0 & 15 & \\
\hline Traumatic & 4 & 4 & 0 & 0 & 0 & 0 & 0 & 0 & 0 & 0 & 0 & 8 & \\
\hline Armed forces & 1 & 2 & 0 & 0 & 0 & 0 & 0 & 0 & 0 & 0 & 0 & 3 & \\
\hline Oncology & 0 & 1 & 3 & 1 & 0 & 0 & 0 & 0 & 0 & 0 & 0 & 5 & \\
\hline Radiology & 0 & 0 & 0 & 1 & 1 & 0 & 0 & 0 & 0 & 0 & 0 & 2 & \\
\hline Orthopedics & 1 & 0 & 1 & 1 & 0 & 0 & 0 & 0 & 0 & 0 & 0 & 3 & \\
\hline General practice & 2 & 3 & 1 & 0 & 2 & 0 & 0 & 0 & 0 & 0 & 0 & 8 & \\
\hline Ophthalmology & 0 & 0 & 1 & 0 & 2 & 0 & 0 & 0 & 1 & 0 & 0 & 4 & \\
\hline Pathology & 1 & 1 & 0 & 0 & 0 & 0 & 2 & 0 & 0 & 0 & 0 & 4 & \\
\hline Gastroenterology & 1 & 0 & 0 & 1 & 0 & 0 & 0 & 0 & 0 & 0 & 0 & 2 & \\
\hline Nephrology & 1 & 0 & 1 & 0 & 0 & 0 & 0 & 0 & 0 & 0 & 0 & 2 & \\
\hline Total & 59 & 58 & 37 & 35 & 33 & 8 & 22 & 1 & 6 & 3 & 7 & 269 & \\
\hline
\end{tabular}

$+p<0.01$, statistically significant

rewarding and in spite of the long working hours, it was their correct decision regarding this professional choice. Study done by Philip shows that academic or research opportunities were an important factor for students (58\%) choosing pediatrics [33]. Our findings regarding the Obstetrics and Gynecology preferred students were identical with a study done by Scott, in Canada where he found that students had a strong social orientation compared with students opting other surgical specialties [34]. This study corroborates the results of a previous research done by Thakur, where Medicine as a specialty opting students wiling to dedicate themselves for their home country. Most of the Nepalese population stay far away from primary health care and die hastily. This motivated many students to choose this profession for the improvement of the health status of their society, chiefly rural population [35].

Medical Science 2013;1(1): 3-11

Copyright @ 2013 CMRA

www.medicalscience.pubmedhouse.com

\section{Conclusion}

This study revealed that interest in human body, helping people, social contact with people, practical aspect of profession and variety of scope was the major determinants associated with choice of career. We should be careful about the preference for the choice of specialties; they probably need much guidance in career selection. This can be achieved by various constructive steps like inclusion of factors concerned with the choice of medical career in the selection events of medical schools and post-graduate training, sufficient and regular career guidance with a collaborative approach between college authority and Medical Council related to future demands for doctors. Results of such longitudinal research based on career selection, fascination, drawbacks of different specialties for the development of future medical doctors must be spread among the budding doctors. The findings of this study can provide ample career guidance for future medical doctors and help them to fill the gap in different medical specialties. 


\section{Future scope of the study}

Outcomes of our present study are quite interesting and we believe it will encourage other researchers to do further broad spectrum studies. Students are optimistic about the future. Major determinants motivating students towards specialization branches are interest, helping people, social contact, practical aspect and scope in the profession. Multicentre study with a large sample size may be helpful for future career guidance.

\section{Abbreviations}

MCOMS: Manipal College of Medical Sciences, OBG: Obstetrics and Gynecology.

\section{Competing interests}

The authors do not have any conflict of interest arising from the study.

\section{Authors' contribution}

$\mathrm{BR}^{1}$ designed the study, deduced the data, drafted the manuscript, and revised it. $\mathrm{IB}^{3}$ and $\mathrm{BS}^{4}$ planned the study acquired the data, conducted the data analysis, interpreted the data, and revised the manuscript. $I B^{2}$ has participated in the language editing along with $\mathrm{BR}^{1}$. $\mathrm{BS}^{4}$ and $\mathrm{IB}^{2}$ participated in statistical analysis, interpreted the data, and revised the manuscript.

\section{Acknowledgments}

We lengthen our heartfelt and cordial gratitude to Dr. B. M. Nagpal, Dean and CEO, MCOMS, Nepal, for giving constant support.

\section{Authors' information}

${ }^{1}$ Dr. Bedanta Roy, Currently working as Assistant Professor in the Department of Physiology, Manipal College of Medical Sciences, Pokhara, Nepal. His PhD work is in Neurophysiology.

${ }^{2}$ Dr. Indraneel Banerjee MBBS, M.S. MRCS ( Eng )

RMO cum clinical tutor (Urology)

Calcutta National Medical College, Kolkata, India.

${ }^{3}$ Dr. Indrajit Banerjee MBBS, MD Pharmacology. Currently working as aLecturer in the Department of Pharmacology, Manipal College of Medical Sciences, Pokhara, Nepal.

${ }^{4}$ Dr. Brijesh Sathian MD(AM), PhD. working as Assistant Professor and Biostatistics Chief in the Department of Community Medicine, Manipal College of Medical Sciences, Pokhara, Nepal. He is the editorial board member of NJE, IJBS, AlIJMS, GMJ.

Medical Science 2013;1(1): 3-11

Copyright (c) 2013 CMRA

www.medicalscience.pubmedhouse.com
${ }^{5}$ Dr. N Suresh Baboo, DNB, M.D

Professor in the Department of Physiology, Manipal College of Medical Sciences, Pokhara, Nepal.

\section{References}

1. Wright B, Scott I, Powis D, Woloschuk W, Henry R, Turnbull $D$, et al. Career preferences of new medical students at four Australian universities: Rural family medicine versus the rest. Aust J Rural Health 2006;14:229-30.

2. Mihalynuk T, Leung G, Fraser J, Bates J, Snadden D. Free choice and career choice; clerkship electives in medical education. Med Educ 2006, 40:1065-71.

3. Mutha S, Takayama JI, O'Neil EH. Insights into medical students' career choices based on third- and fourthyear students' focus-group discussions. Acad Med 1997;726:35-40.

4. Fincher RM, Lewis LA, Rogers LQ. Classification model that predicts medical students' choices of primary care or non-primary care specialties.Acad Med 1992;67:3247.

5. Kassebaum DG, Szenas PL, Schuchert MK. Determinants of the generalist career intentions of 1995 graduating medical students.Acad Med 1996;71:198-209.

6. Dorsey ER, Jarjoura D, Rutecki GW. The influence of controllable lifestyle and sex on the specialty choices of graduating U.S. medical students, 1996-2003.Acad Med 2005;80(9):791-6.

7. Lambert EM, Holmboe ES. The relation between specialty choice and gender of U.S. medical students, 1990-2003.Acad Med 2005;80(9):797-802.

8. Tonkin P. Effect of rising medical students debt on residency specialty selection at the University of Minnesota. Minn Med 2006;89(6):46-7.

9. Batenburg V, Smal JA, Lodder A, De Melker RA. Are professional attitudes related to gender and medical specialty. Medical Education 1999;33:489-92.

10. Roy B, Banerjee I, Sathian B, Mondal M, Kumar SS, Saha CG. Attitude of Basic Science Medical Students towards Medicine and Surgery Post Graduation: A Questionnaire based Cross-sectional Study from Western Region of Nepal. Nepal Journal of Epidemiology 2010; 1(4):126-34.

11. Banerjee I, Jauhari A C, Bista D, Johorey A C, Roy B and Sathian B, Medical Students View about the Integrated MBBS Course: A Questionnaire Based Cross-sectional 
Survey from a Medical College of Kathmandu Valley. Nepal Journal of Epidemiology 2011;1(3): 95-100.

12. Karki DB, Dixit H. An overview of undergraduate and postgraduate medical education in Nepal and elsewhere. Kathmandu Univ Med J (KUMJ) 2004;2(1):69-74.

13. Woodworth PA, Chang FC, Helmer SD. Debt and other influences on career choices amongsurgical and primary care residents in a community-based hospital system. Am J Surg 2000;180:570-5; discussion 575-6.

14. Zulkifli A, Rogayah J. Career preferences of male and female medical students in Malaysia.Med J Malaysia 1997;52(1):76-81.

15. Al-Faris E, Kalantan K, Al-Rowais N, et al. Career choices among Saudi medical students.Acad Med 1997;72(1):65-7.

16. Karalliedde LD, Senanayake N, Aluwihare AP. Career preferences of the 1984 medical graduates of Sri Lanka. Med Educ 1986;20(1):64-8.

17. Nieuwhof MG, Rademakers JJ, Kuyvenhoven MM, Soethout MBM, Ten Cate JJ. Students' conceptions of the medical profession; an interview study. Med Teach 2005;27(8):709-14.

18. Marc BM Soethout, Olle TJ ten Cate, Gerrit van der Wal. Correlations of knowledge and preference of medical students for a specialty career: a case-study of youth health care. BMCPublic Health 2008, 8:14.

19. Sathian B, Sreedharan J, Baboo N S, Sharan K, Abhilash E S, Rajesh E. Relevance of sample size determination in medical research. Nepal Journal of Epidemiology 2010;1(1): 4-10.

20. Huntington I, Shrestha S, Reich NG, Hagopian A. Career intentions of medical students in the setting of Nepal's rapidly expanding private medical education system. Health Policy Plan.2012 Aug;27(5):417-28.

21. Khader Y, Al-Zoubi D, Amarin Z, Alkafagei A, Khasawneh M, Burgan S, El Salem K, Omari M. Factors affecting medical students in formulating their specialty preferences in Jordan.BMC Med Educ. 2008 May 23;8:32.

22. Scott IM, Abu-Laban RB, Gowans MC, Wright BJ, Brenneis FR. Emergency medicine as a career choice: a descriptive study of Canadian medical students. CJEM. 2009 May;11(3):196-206.

23. Shaikh T. B, Kahloon A, Kazmi M, Khalid H, Nawaz K, Khan A N and Khan S. Students, Stress and Coping
Strategies: A Case of Pakistani Medical School. Education for Health, Vol.17, No. 3, Nov 2004, 346-53.

24. Tennakoon HD, Vidanapathirana AK, Sutharsan S. Career preferences and the factors influencing their selection in fourth year medical studentsin the University of Colombo. Student medical journal faculty of medicine, Colombo. 2008;1(1):20-26.

25. Harth SC, Biggs JS, Thong YH. Mature-age entrants to medical school: a controlled study ofsocio-demographic characteristics, career choice and job satisfaction. Med Educ. 1990 Nov;24(6):488-98.

26. Banerjee I, Roy B, Sathian B, Banerjee I, Kumar SS, Saha A. Medications for Anxiety: A Drug utilization study in Psychiatry Inpatients from a Tertiary Care Centre of Western Nepal. Nepal Journal of Epidemiology 2010; 1(4):119-25.

27. Banerjee I, Roy B, Banerjee I, Sathian B, Mondal M, Saha A Depression and its Cure: A Drug Utilization Study from a Tertiary Care Centre of Western Nepal. Nepal Journal of Epidemiology 2011; 1(5): 144-152.

28. Troppmann KM, Palis BE, Goodnight JE, Ho HS, Troppmann C. Career and lifestyle satisfaction among surgeons: what really matters? The National Lifestyles in Surgery Today Survey. J Am Coll Surg. 2009 Aug;209(2):160-9.

29. Cavanagh SJ, Snape J, Ellis A. Occupational stress in neurosurgery: an exploratory study. J NeurosciNurs. 1992 Dec;24(6):329-34.

30. FontánAtalaya IM, DueñasDíez JL. Burnout syndrome in an obstetrics and gynaecology Management unit.RevCalidAsist. 2010 Sep-Oct;25(5):260-7. Epub 2010 Jul 10.

31. Panagopoulou E, Montgomery A, Benos A. Burnout in internal medicine physicians: Differences between residents and specialists.Eur J Intern Med. 2006 May;17(3):195-200.

32. Waldman SV, Diez JC, Arazi HC, Linetzky B, Guinjoan S, Grancelli $\mathrm{H}$. Burnout, perceivedstress, and depression among cardiology residents in Argentina. Acad Psychiatry. 2009 Jul-Aug;33(4):296-301.

33. Philip MM, Eric MT. Factors influencing choice of paediatrics as a career among medical students at the University of Nairobi, Kenya. SAJCH .2010 Sep4(3):7072.

34. Ian M. Scott, Nasmith T, Margot C. Gowans, M Nut D,1 Bruce J. Wright, Fraser R. Brenneis, Obstetrics and 
Gynaecology as a Career Choice: A Cohort Study of Canadian Medical Students .JOJC. Nov2010,1063-69.

35. ThakurA, Ashokraj G, Koirala S. Medicine as a career choice: motivating factors in Nepalese medical students. J InstMed . 1999;21: 1-18.

Published on 30.5.2013

Submit your next manuscript to Medical Science and take full advantage of:

- Expedient online submission

- Thorough peer review

- No Publication fee

- No space limitations or color figure charges

- Immediate publication after acceptance

- Research which is freely available for redistribution

Submit your manuscript at medicalscience@pubmedhouse.com 